JERZY ONISZCZUK ${ }^{1}$

\title{
Polis as the Prototype of a Contemporary Community
}

\begin{abstract}
The Greek polis is the birthplace of a culture whose influence persisted despite the fall of the very form of polis. This culture plays a significant part in the life of communities of today, especially in the domain of the so-called Western culture. Polis means both state and city, but most of all it is "a society, a community of people living together". This form of governance enabled equal citizens to exercise direct supervision over their governments. Polis itself was not an invention of ancient Greeks, but the public nature thereof, especially in the form of the debate-based democracy and the rule of law - not of people - turned out to be their contribution to the idea of a city-state. Democracy as a common form of a political system can be found particularly in the Greek culture of polis.

The general notions deriving from the Greek polis, i.e. citizenship, democracy, equality, independence, autonomy or justice, express a desire for a better life of an individual in a community. The democracy of classical times, characterised by equal citizenship and freedom of speech, is considered as the first one to moderate fierce social-economic disputes. It is this polis that made it possible for philosophy and science to develop. The modern-day discussion on the state in a globalised and increasingly urbanised world can surely benefit from a reflection on the civil and legal dimensions of polis.
\end{abstract}

Keywords: ancient Greece, polis, community of polis, institutions of polis, democracy, Athens, independence, political rule, freedom, equality, justice, rule of law, archaic period

1 Prof. Jerzy Oniszczuk, PhD - Department of Public Administration, SGH Warsaw School of Economics; e-mail: jonisz@sgh.com.pl; ORCID: 0000-0003-4526-7334. 


\section{Introduction}

The phenomenon of polis $^{2}$ is commonly considered to impart a great cultural significance to the entire antiquity. Polis is the breeding ground of political institutions that shaped the lives of Greeks in the archaic, classical, and Hellenist times, and even under the Roman reign. Polis is treated as the birthplace of a culture whose influence has not died down despite the fall of the very form of polis; this influence is felt also today in the lives of communities, especially in the domain of the so-called Western culture. Although polis was not the only nor a dominant form of the socio-political organisation of the life of people from ancient times, its nature has been of lasting value to researchers on account of validity of the issues it originally addressed, starting from the thought behind the emergence of polis. Interestingly, polis was also a place where such an extraordinary phenomenon as philosophy ${ }^{3}$, aimed at understanding the cosmos and human nature came into being. Namely such poleis as Miletus, Ephesus, and later Athens can be regarded as turning points marking the transition from mythological to philosophical thinking and fostering the creation a "scientific form" of homo sapiens. Within Greek poleis first attempts to explain various phenomena using arguments pointing to nature, causality or reason took place 4 . The civic debate of the ancient era (630/600-460/438 BC) produced notions crucial for functioning and understanding of poleis, especially of democracy and the state of law.

The term polis means both state and city, but most of all it is "a society, a community of people living together". Polis also turned out to be a form of governance in the Greek landscape, one that made it possible for equal citizens to exercise direct supervision over their governments. But polis is also a state of loyalty felt and shared by the inhabitants of this form of community life ${ }^{5}$. Polis itself was not

2 As for terminology, see: M.H. Hansen, Polis. Wprowadzenie do dziejów greckiego miasta-państwa w starożytności, transl. by A. Kulesza, R. Kulesza, Warsaw 2011, pp. 78, 103, 105-106, 109-110.

3 G. Reale, Historia filozofii starożytnej, vol. 1, trans. by Edward I. Zieliński, Lublin 2008, p. 51 and quoted Zeller.

4 M. Szczęśniak, Nauka a demokracja, in: Filozofia a demokracja, ed. by P.W. Juchacz, R. Kozłowski, Poznań 2001, p. 277.

5 W. Lengauer, Starożytna Grecja okresu archaicznego i klasycznego, Warsaw 1999, p. 19; J.M. Hall, Polis, Community, and Ethnic Identity, in: The Cambridge Companion to Archaic Greece, ed. by H. A. Shapiro, Cambridge University Press 2007, p. 40. 
invented by the ancient Greeks. It is rather the public nature thereof, especially in the form of the debate-based democracy, that became a specific form of organisation of the political life of the Greeks; and it is the Greeks' contribution to the idea of a city-state.

In Aristotle's description, a polis was defined as a "political community of citizens" (politeia). A polis was composed of citizens (politai); it was therefore a "civic community" made up of adult men with certain rights ${ }^{6}$ and duties (e.g. defence) ${ }^{7}$. Aristotle would also refer to a polis as a formation composed of houses or people. But a polis differed from other urban agglomerations in its political status; it was a political community (a state). A polis therefore included a city (with the surroundings and supporting infrastructure - chora, i.e. the country) and a state (a political entity). The more recent descriptions of polis rule out the existence of a polis (i.e. a state) without a political centre in a city, but also of a polis as a city that would not be a state's political centre at the same time. Speaking in the most general terms, every polis-city has been defined as a "polis-state centre, and every polis-state is considered to have had a polis-city functioning as the state's political centre" ${ }^{\prime \prime}$. In the Hellenist period, polis ceased to be understood as a fortified settlement (acropolis).

A significant quality of a polis, especially of a democratic one, is equality. In the early-archaic period, the economic differences between the inhabitants-members of poleis were not considerable. No intransgressible, class-related borders were present either. Moreover, the special status of aristocrats, who rendered great military service to poleis, was not questioned. That is why the demand for equality was not frequent or common. The greater expenditure on public objectives of the wealthy was treated as something natural. And these circumstances promoted an attitude of consent to the greater political influence of aristocracy on community life. Despite the absence of greater economic differences among the members of a political

6 Aristotle, Politics (Book III, Chapter I, 1275a, 1276b).

7 B. Bravo, E. Wipszycka, Historia starożytnych Greków, vol. I, Do końca wojen perskich, Warsaw 1988, pp. 129-130.

$8 \quad$ M.H. Hansen, Polis ..., pp. 85-86, 89-91, 152-153. The Greek understanding of a polis as a community is supported also by the names of cities as they came from local names referring usually to peoples, not to regions. "The largest city in Boiotia in antiquity was Thebai (Thebes), and derived from the toponym was the adjective Thebaios (Theban), which in the plural form Thebaioi (the Thebans) designated the citizens of that city-state and, in a more general sense, the city-state itself. (...). In antiquity it was the Thebans (and not Thebes) that was the leading state in the Boiotian Federation. This difference in naming conventions highlights two differences between modern states and the city-states of antiquity. In our conception of the state, the main weight is given to the territory of the state, its land, and so the toponym is the name of the state. The Greeks placed the main weight upon the people of the state, and so used the ethnikon as the name of the state (...). Hence the name of a state (e.g. the Thebans) was derived from the place-name of the city (Thebes) and not from the place-name of its land" (ibidem, pp. 91 and 92 and the literature quoted therein). 
community and despite the absence of calls for equality, the life of a polis was not all peaceful. Conflicts were actually ingrained in the nature of a polis since its political system was characterised by the need for a constant vying for power between individuals and groups. This also meant vying for power using force ${ }^{9}$.

The archaic city in question, paving the way for the development of the culture of polis, gives birth to various public and cultural institutions, shapes a particular attitude to religion, a range of social structures, and a certain "model" of intra-community relationships and relations with other cities.

\section{The formation of the Greek poleis. The equality-oriented trend}

Worth exploring are the origins of Greek poleis, considered as small self-governing communities, usually limited to the territory of one city and its vicinity. It is argued that they did not appear at the same time across the entire area of the Greek civilisation as a result of a dissolution of some great state. The question is therefore about the time, the place, and the conditions of emergence of the form and culture of polis. It is usually said that the culture of the Greek polis dates back to the $8^{\text {th }}$ century BC. It is worth noting that some form of polis existed already close to the end of the Greek Dark Ages, which is to be proven by descriptions featured in Homer's works, resembling that of Aristotle's, with the latter claiming that "man is naturally inclined to live in a polis" (Politics) ${ }^{10}$. In the Homeric Age a pre-polis exists; its centre is a temple and a gathering place for the community to assemble (agora), and the founding of the city is described in the Book 6 of the Odyssey ${ }^{11}$. Homer's poetry does not deal with the life of Troy; it is a subject far from the described military events ${ }^{12}$. Speaking in most general terms, it is believed that the Homeric Age (900-700 BC) was a period of the simultaneous emergence of cities and states, but also of the establishment of the specific Greek form and culture of polis as we know it. Various factors are mentioned as the components of the foundation for

$9 \quad$ B. Bravo, E. Wipszycka, Historia..., p. 136.

10 Homer, for instance, wrote that Cyclops were uncivilised because: "They have no meeting place for council, no laws either, no, up on the mountain peaks they live in arching caverns - each a law to himself, ruling his wives and children, not a care in the world for any neighbour". Odyssey, Book 9, 115 et seq.

11 "So their godlike king, Nausithous, led the people off in a vast migration, settled them in Scheria, far from the men who toil on this earth - he flung up walls around the city, built the houses, raised the gods' temples and shared the land for plowing". Odyssey, Book 6, 7-10.

12 B. Patzek, Homer i jego czasy, Warsaw 2007, pp. 88-89. 
its development - mainly demographic and economic ones ${ }^{13}$. Literature associates the process of formation of polis also with the necessity of working together when building grand temples ${ }^{14}$.

As for the way in which poleis emerged, the most common theory is that it happened as a result of a natural development, through colonisation (apoikismos) or synoecism (synoikismos) ${ }^{15}$. The said natural development was a long-term process and there are not many sources that could make it possible to determine the moment in which city inhabitants started becoming conscious citizens of poleis. The vast majority of poleis came into being in the archaic period, which happened early enough that the notion of polis did not take shape yet as the fundamental idea to the Greek philosophical-political thought. This was the period when the emergence of poleis was not associated with natural evolution. Instead, many Greeks believed that poleis were created by some god or demigod, and in the case of colonies it was thought that it was some hero-like aristocratic leader of colonists. The classical period, when the notion of polis was already fully-fledged, does not provide any reflection on the natural establishment of cities. In the Hellenist times and in the period of the Roman Empire, in turn, some communities could be granted the status of a polis by way of a sovereign's act ${ }^{16}$.

Among the various versions of the origins of polis, one may recall the theory of the existence of a city-state culture in mainland Greece in places where colonisation was initiated, i.e. Euboea (cities of Chalcis and Eretria), the Isthmus (Corinth and Megara), in Lacedemonia (Sparta), Argolis (Argos), Attica (Athens) or on the islands of the Aegean Sea such as Paros, Naxos, and Crete. Crete, however, is given particular credit on account of the fact that it is a place where the oldest Greek laws remained kept and where the earliest fortifications can be found. This is accompanied by a conjecture that the Cretan version of the Greek culture was one characterised by a preservation of continuity between the Bronze Age and the Iron Age. This conjecture led to a speculation that the culture of polis emerged in the first millennium as a consequence of efforts aimed at restoring the city-state culture of the second millennium ${ }^{17}$.

13 M.H. Hansen, Polis..., p. 215.

14 Ibidem, p. 185 and quoted M.E. Voyatzis.

15 Synoecism meant migration of groups of people within adjoining areas or to inhabited settlements or to uninhabited lands where cities would be established. M.H. Hansen, Polis..., p. 79 and quoted T.H. Nielsen.

16 M.H. Hansen, Polis..., pp. 78-79 and quoted Pherecydes, Thucydides, as well as Hornblower and Schuler.

17 Ibidem, Polis..., p. 70 and quoted Camp. 
At the beginning of the $8^{\text {th }}$ century BC (the pre-archaic era), a clear tendency to form autonomous political communities was in place. And this is why the main issue to be considered is how a society emerging from the Dark Ages, one relatively short-lived, lacking broader social instruments, appeared to be able to construct a civic community aware of the value of equality, justice, freedom, jointly-made political decisions, and reason. The situation can be explained e.g. by the fact this society emerged on the grounds of not fully developed social institutions and of uncertainty regarding the exercise of leadership. On the one hand, there was the emergence of elite forms of life, i.e. aristocracy composed especially of tribal chiefs and various heroes. On the other, there was the development of egalitarian trends connected with the nature of citizen armies. With the twilight of the Dark Ages, the separation of aristocracy was not yet based on an economic criterion. What mattered was the social background and the lifestyle of aristocrats. The clash of the aristocratic world of honour with the justice-oriented vision of common people was to become visible with the increased significance of institutions born in poleis. The appearance of structural antinomies, which were later supported by the new institutions of polis, are described as a source of "transformations as sudden and extreme as never before in the entire history"18. The institutions of polis included specific collegial bodies such as: citizens' assemblies and councils, which played the main part in public debates.

The improvement of the economic situation of many poleis, the blooming trade exchange, and the increasing frequency of seafaring - especially between poleis - was of great significance to the development of a community of specific qualities. This was accompanied e.g. by the emergence and development of hospitality among aristocracy in a similar form as described by Homer. Thus, it was the needs and desires of the aristocratic lifestyle that was to give birth to new relationships and interests. The development of poleis was followed by an increasing institutionalisation of the situation of aristocracy, meaning that aristocrats holding the highest positions appeared to be representatives of the community. Therefore, the private relationships of aristocrats from different poleis became political since they were formed in the area of relationships of an interstate nature. In consequence, the transition from the relations between such forms of "social organisations as aristocratic estates (oikos)" to the relations between such forms as poleis is considered to have laid the foundations for interstate - and international - affairs. This shift in the nature of relationships was to initiate a new type of diplomatic relations, but "vestiges of old-fashioned diplomacy" could still to be encountered later on. They manifested themselves in that in the classical period, poleis appointed their repre-

18 O. Murray, Narodziny Grecji..., pp. 88, 95. 
sentatives in other cities from among citizens of a given city who were also members of the more illustrious families. This is how the "relationship of proxeny, meaning a hereditary relationship of hospitality" came into being. The following transformations of the institution suggest an appearance of official relations of mutual recognition of the autonomy of individual poleis. What was of particular importance to the dissolution of relations typical of the old times and to the emergence of a new type of relations, however, was the period of wars in the last 30 years of the $8^{\text {th }}$ century BC on the Lelantine Plain. They were caused by a conflict between aristocratic states, i.e. Chalcis and Eretria. The conflict arose because both states functioned "in the centre of the trade relationships established by aristocracy, or perhaps for aristocracy and to satisfy their needs". The Lelantine War transformed the traditional trade exchange, severed the ties of collaboration between various Greek cities, contributed to a certain institutionalisation of poleis, and as the "last war fought the old way, between leaders", it put an end to the age of such conflicts ("gentlemen's wars") ${ }^{19}$.

Once the Dark Ages come to an end, the Hellas of the $8^{\text {th }}$ century BC develops quickly, iron weapons become less expensive, and traditional groups of warriors and dominant (on account of the military equipment owned and the training undergone) aristocrats give way to multiple-row groups of hoplites (phalanx) ${ }^{20}$. The mechanism employed to making important decisions in the new type of army turned out to be a debate involving exchanging arguments aimed at convincing and winning others over. These attributes are characteristic of democracy ${ }^{21}$. The phalanx formation, which was about joint defensive and offensive actions, required discipline and mutual trust. As a result, the army laid the foundation for the thought of a society of equal members fighting for a common cause. The list of persons of merit, recognised as having rendered great service to the community, tended to grow longer. The new hero - hoplite - did not turn to wealth or personal military achievements to claim authority; instead, hoplites would make their claims based on the power of a mass military organisation and its service rendered to the city. The question of hoplites' right and duty to defend their homeland appeared. As its defenders, they gained the right - next to aristocrats - to decide in matters concerning their community, to establish laws. This hoplite novelty limited the military

19 O. Murray, Narodziny Grecji..., pp. 107-109. See also: N.G.L. Hammond, Dzieje..., p. 179. The effects of the war are said to have contributed to the abandonment of the Lefkandi village, which is argued to have been continuously occupied since the Mycenaean period.

20 Hoplite's weaponry appeared on vases and figurines already around year 700 BC. N.G.L. Hammond, Dzieje..., pp. 151 et seq., 182.

21 It is said that democracy is an exceptional product of military science. See: J. Długosz, “Obywatel hoplita", supplement to Polityka 23.03.2006, pp. 36-37. 
significance of aristocracy to a considerable extent, which also undermined the latter's leadership in the community. A democratic army was being born. One whose modus operandi and where the status of a soldier began shaping the range of rights and obligations in poleis. Equality was no longer an internal matter of aristocracy. It became also an attribute of hoplites - citizens, making its way to cities. As they strived for power, the political 'worth' of members of the community became more equal, and the pro-democratic trend gained in significance. The equal hoplite appeared to be a factor of great social-democratic importance.

The egalitarian trends of poleis could also be seen in the practice of establishing and maintaining colonies at remote and often hostile places. In this context, the relationships between colonists, governed usually by aristocrats, had to take on collaboration favouring equality into greater account. Therefore, the development of awareness originating from Greek colonies is considered to be of great significance to the idea and practice of polis-specific democracy and the equality and freedom related thereto. Quite convincing seems the interpretation that the success of colonists who "set about to divide the land and live without aristocratic reign »on equal terms «" could have affected the collapse of aristocratic rule in metropolises in the $7^{\text {th }}$ century BC. The culture shock caused by the values of equality and freedom of the New World of the time is evidenced by the complaints of "aristocratic poets on the lamentable fact that wealth means more than good breeding in the new era" 22 .

The traditional politai community was characterised by the absence of impassable social barriers, although the aristocratic background played a part as well. The later internal social differences resulted, in turn, from economic factors. On the one hand, there were the wealthy, referred to as esthloi (noble), agathoi (valuable) or aristoi (the best). On the other hand, there were the kakoi (vile, evil), deiloi (of little worth). Despite the social disparity, no separate 'classes' took shape in the archaic era, and misfortune could make an aristos become a kakos, and a kakos who became wealthy enough could become an aristos. Although "the best" tended to stress their social superiority, it is argued that a strong sense of community prevailed in poleis, which made it difficult for aristocracy to form a closed group. The homogeneity of the community was supposed to be influenced by similar desires and preferences of both the more and the less well-off members of a given society. The differences between them showed in their opportunities to fulfil their needs. They shared the same beliefs, listened to the same epic poems, had similar morality and ambitions expressed in their desires to free themselves from the hardships of labour. They longed for being actively involved in sports, politics, battles or hunt-

22 O. Murray, Narodziny Grecji..., p. 168. 
ing. This was the basis for the formulation of the view concerning the fundamental feature of the social order of ancient Greece. This feature was said to involve a co-occurrence of "a sense of community and strong conflicts within such a community". Thus, the image of an epoch abounding in battles can be considered complete if both of the said aspects are taken into account ${ }^{23}$.

\section{The cultural homogeneity of poleis and its universalisation. The independence and autonomy of poleis}

There were around 1,500 poleis in the history of Greek city-states (from around $750 \mathrm{BC}$ to $550 \mathrm{AD}$ ). The Greek culture of cities-states lasted about 1,200 years, but it was not the longest-lasting such culture in history as Sumer and Babylonian city-states existed even longer. But when it comes to the number of city-states, to their population, and to their territorial reach, the Greek culture is the largest such culture in human history. It is supposed that in the $4^{\text {th }}$ century BC, the Greek poleis were populated by a total of 7.5 million people. In the Roman Empire period, this number amounted to around 30 million people ${ }^{24}$. The culture of a city-state proved its value both in relation to the internal affairs of the polis as well as outside, in relation to other cities. It could stretch over a huge area and exist in diverse conditions. It proved to be flexible and efficient.

Despite the great number of poleis, scattered across a significant area and functioning over a thousand years, inhabited by huge populations, it is generally agreed that those poleis shared many common features and belonged to one civilisation ${ }^{25}$. One such important feature of the polis culture is that city-states existed in separation from one another. The question here is the reason for this separation, maintained in a situation in which the inhabitants of different cities share the same ethnic identity (culture, history, language, customs, religion) across the entire area of the polis culture. The differences were about the political identity and the sense of patriotism shared among the citizens of each polis. The citizens of poleis related these two qualities to their own city-states, and this circumstance made individual poleis differ from one another ${ }^{26}$. A Greek identifying themselves, as a citizen, with

\footnotetext{
23 B. Bravo, E. Wipszycka, Historia..., p. 131.

24 M.H. Hansen, Polis..., pp. 22-26 and on the longevity of Sumer and Babylonian city-states, see: M. van de Mieroop, The Ancient Mesopotamian City, Oxford 1997, p. 6.

25 Greek cities stretched over lands from Empúries (Pyrenees) to Ai-Khanoum (Afghanistan), from Olbia (Ukraine) to Cyrene (Libya). M.H. Hansen, Polis..., pp. 13, 18, 19, 29, 47-48, 240.

26 M.H. Hansen, Polis..., p. 97.
} 
a particular polis, but also being a member of an all-Greek community, is considered an important feature of the Greek mentality. On the one hand, this awareness prevented Greek culture from becoming "local", and on the other, it contributed to the universal meaning of the cultural achievements of Greek culture taking shape in different places. Importantly enough, the awareness of a shared culture did not translate into a clear need to establish a single political structure ${ }^{27}$, although the idea of political unity happened to be spoken of by politicians and philosophers. Despite the various forms of domination (unions, federations), polis remained a fundamental Greek political structure. There were therefore no cases of depriving cities that became subordinate (by finding themselves in the territory of small empires that grew around some poleis) of their nature (e.g. Sparta, Syracuse) ${ }^{28}$.

The principle of identity plays a considerable role in comparing a city-state with a country-state. The main difference between them is about the essence of their identity. A state is mostly oriented towards its territory while a polis is formed by a community. Both organisms share a set of common features: a territory, a population (citizens in the political sense and inhabitants in the legal sense), and a system - of political institutions establishing the binding legal order. But a state and a polis are not just some three-element beings. They are expressed in the form of public authority of an abstract nature, situated above the governing and the governed $^{29}$. The sense of the public authority of a polis and a country-state is different, though. Greeks realised the difference between a state and a polis when they compared the self-government system of poleis with the governing mechanisms adopted in neighbouring Asian countries, like in Persia. The comparison led philosophers to the conclusion that it was possible to practice the rule of politics only in a self-governing polis or a republic. It was believed that politics was impracticable in Persia, where the king was a master of a nation of slaves, not a ruler of a community of citizens ${ }^{30}$. Thus, according to this view, democracy may occur only if citizens are able to participate in politics.

It was mentioned that poleis existed in separation although Greeks were aware of their cultural uniformity. To supplement the argument, it is worth adding that the most general feature of a city-state was its autonomy. But it is usually not described as an equivalent to a complete political independence ("external" sovereignty). In the past, independence was treated as a constitutive feature of a polis. The inter-

27 B. Bravo, E. Wipszycka, Historia..., p. 137.

28 M.H. Hansen, Polis..., pp. 83-84 and quoted Aristotle, Politics.

29 M.H. Hansen, Polis..., p. 98.

30 A. Ryan, On Politics. A History of Political Thought. From Herodotus to the Present, Book One, New York-London 2012, pp. 5-6. 
pretation was based on a desire to characterise polis from the perspective of the $19^{\text {th }}$-century understanding of statehood. The approach is considered wrong in the light of e.g. the practice of contemporary federations, under which member states have no full autonomy. Apart from establishing external relationships according to an individually determined autonomy, a polis exercised authority and enforced law upon its people within a certain area on its own - so-called "internal" sovereignty ${ }^{31}$ (self-governance).

From the moment of the establishment of poleis until their disappearance, particular cities enjoyed different levels of independence. As a result of migration, colonisation, trade, various disputes between individual poleis and in relation to country-states, different relationships of dependence among poleis appeared. The most general evaluation of the entire world of poleis questions the argument of them forming a system of equally independent beings. Instead, they are viewed rather as forming a complex hierarchy of cities of a smaller and greater autonomy, but always enjoying freedom regarding their internal - self-government - matters. The common state of dependence of poleis is associated with the Hellenist period. In the case of cities of mainland Greece, they became members of federal states (the Achaean League and the Aetolian League). Federal institutions performed different functions on behalf and for an entire community, dealing especially with foreign policy and union judicature affairs. In federations, the notion of a union citizenship next to the traditional citizenship of a polis also appeared. As the significance of federal states grew, the collaboration between different poleis became closer, and when any disputes between cities occurred, they were resolved by means of arbitration. Finally, there appears to have been a large number of treaties signed between poleis, which led to a view that the discipline and practice of international law emerged in the Hellenist period ${ }^{32}$.

\section{The political freedom of citizens and the precedence of law}

The Greek political vision of polis was distant from the concept considering a lawgiver as a master standing above the law. According to this vision, absolute power means tyranny and a community could even lose its character of a polis. This characteristic of polis - the precedence of law ${ }^{33}$ over the will of an individual - made it possible for a citizen to become politicised. In his famous tragedy entitled The

\footnotetext{
31 M.H. Hansen, Polis..., p. 19.

32 M.H. Hansen, Polis..., pp. 204-206, 210-211.

33 M.H. Hansen, Polis..., p. 97; N.G.L. Hammond, Dzieje..., p. 188 et seq.
} 
Suppliants, Euripides wrote as follows: "Nothing is worse for a city than a tyrant, because, first of all, the laws are not held in common, but one man, possessing the law, holds the power at his side. No longer is there equality. When laws have been written down, the weak and the rich have justice that is equal. The weaker accost the fortunate with the same words, when his reputation is impugned. The lesser man, with a just case, defeats the big man. This is freedom: »Who has a plan beneficial to the city and wishes to bring it into the middle? He who desires shines, and whoever does not is silent!" 34 . Importantly, the claims for a common, written law, providing normative certainty, dated back to the $7^{\text {th }}$ century BC. They were expressed in e.g. Hesiod's deliberations (Works and Days) as well as in the oldest existing codes, e.g. the Lycurgus code, the Draconian code, or the Cretan codes of Gortyn ${ }^{35}$. It was also Hesiod who initiated a language expressing the "self-awareness" of a Greek polis. And it is him - not Homer - who is considered as standing "on the eve of Greek political thought, as in the case of Greek science or theology"36.

As for the existence of the said Greek claim that politics can be practised in a polis if its citizens are equal and if there is a binding law in place, one can refer to Demaratus' - Sparta's expelled king - words spoken in 480 BC to Xerxes, the ruler of Persia. According to Herodotus, Demaratus argued that Spartans fighting together were "the bravest of all" because even though "they be free-men, they are not in all respects free; law is the master whom they own; and this master they fear more than thy subjects fear thee. Whatever he commands they do; and his commandment is always the same: it forbids them to flee in battle, whatever the number of their foes, and requires them to stand firm, and either to conquer or die." ${ }^{\prime 37}$ The view of law ruling free Spartans is also expressed in an epitaph found in Thermopylae: "Go tell the Spartans, thou who passest by, that here obedient to their laws we lie" 38 . Greeks were depicted as free but self-disciplined citizens; differing from Persians, acting under compulsion. A polis would be governed by a ruler, aristocracy or an assembly, and their main attribute was independence ${ }^{39}$. Especially in the case of democracy, citizens (polites) participating in the establishment and enforcement of law were willing to subject themselves to this law as

34 Euripides, The Suppliants, 429-441; A. Krawczuk, Mity, mędrcy, polityka, Warsaw 1975, p. 212.

35 E.g. J. Oniszczuk, "Hezjod: prefilozofia pracy, sprawiedliwości i hybris", in: Prawo pracy. Między gospodarka a ochrona pracy. Księga jubileuszowa Profesora Ludwika Florka, Warsaw 2016, p. 294 et seq.

37 Herodotus, The Histories, Book VII.

38 R. Kulesza, Sparta w V-IV wieku p.n.e., Warsaw 2003, p. 191; T. Zieliński, Grecja niepodległa, Warsaw 1995, p. 188.

39 A. Ryan, On Politics. A History of Political Thought..., pp. 7, 16. 
a result of an awareness different than that of Persians. And this awareness is reflected in e.g. Socrates' motivation to subject himself to an unjust conviction.

\section{The scope of authority. "The rule of many" and struggle for power}

The above remarks open the question of the subjective scope of authority in poleis. Being a part of such authority involved exercising political rights. These rights depended, in turn, on fulfilling one's obligations towards a polis ${ }^{40}$.

Exercising power in an emerging polis in the $8^{\text {th }}$ century BC was a privilege of aristocracy - descendants of those who rose to dominance in the Dark Ages thanks to their military achievements, wealth, and excellence of any kind (arete). The position of aristocrats is said to have been under a significant influence of the attitude modelled after the ethos of Mycenaean heroes. The goal of an aristocrat, especially a young one, was to stand out and gain renown through battles. This brought them worship and veneration, which they lost if disgraced themselves by cowardice and defeat ${ }^{41}$. This was a strong mechanism motivating one to pursue military achievements. Aristocrats' victories made their aspiration for power more legitimate because they could offer the community some non-material assets in the form of their worth as city defenders. The city was the centre of life of aristocracy pushing Greece out of the Dark Ages.

It is worth recalling that the oldest known aristocratic lifestyle, referring to the mythical Mycenaean world (as described by Homer ${ }^{42}$ ), bore fruit in the form of a search for overseas luxury goods and in the development of trade enabling one to become richer quicker than through farming. This lifestyle and ways of accumulating wealth had an impact on other social groups. The opportunities offered by remote lands combined with the threats to the existence of the populations of Greek cities triggered a specific "gold rush" of the time. The hunt for the means of living in an area inhabited by other peoples must have weakened the conservatism of one's own tradition, making it less restrictive, and even imposing some sort of tolerance and openness to otherness and novelty.

The political and economic advantage of aristocracy was reflected in the impact on the awareness of archaic communities - views and preferences of aristocrats

\footnotetext{
$40 \quad$ J. Długosz, Obywatel hoplita..., p. 37.

41 B. Bravo, E. Wipszycka, Historia..., p. 142.

42 J. Oniszczuk, Homer: zasada miary, hybris i absurd "sprawiedliwości”, in: Wspótczesny matrix? Fikcja $w \dot{z} y c i u$ gospodarczym politycznym i społecznym, ed. by J. Osiński, Warsaw 2015, pp. 100-123.
} 
set the standards, examples of living for entire populations. And it was of great significance to the shape of an archaic polis. Aristocrats needed considerable means to make the "Homeric" lifestyle a reality. Wealth determined a family's rank in a city and made it possible to assume leadership ${ }^{43}$. It was a sort of shareholding in power, affecting the amount of 'shares' in it. In a world where such a capitalist shareholding factor determines the shape and form of authority, other mechanisms of authority than those involving a mere set of political-military constraints must emerge. This "capitalist" shareholding of the competing wealthy may have contributed to the emergence of collective bodies and expressed itself in the relationships between people's assemblies and oligarchic councils. The mechanism of aristocracy's collective activity (equal within a class) was most likely a model for democracy to develop.

The relationships between many equal aristocrats (the rule of many) shaped the relationships in a given city. The aspirations of aristocratic families to become wealthier were often accompanied by a desire to assume political leadership. This rivalry involved e.g. a formation of alliances between competing families. They were referred to as stasis ("a group of those who opposed someone"), but the term also meant: "a battle between such groups". Conflicts could pertain to the matter of leadership in a community, holding official positions, wealth or supporters. The significance of disputes is considered in this context as a factor determining the dynamics of community life. But these conflicts also appear to be a source of political emancipation of those who were not members of aristocratic politai. The various aristocratic families, in order to draw other inhabitants of a polis to themselves, had to offer them various benefits, take political action in their interest - which could sometimes be even against the general interest of aristocracy itself. The constant feuds between aristocrats threatened their security. Their assets could be taken over by victors. A dynamic 'migration' of the wealthy could be seen within the aristocratic class. But no individual changes eliminated the duration of aristocracy as a group that was at the helm of poleis ${ }^{44}$.

This state of permanent rivalry between aristocrats in cities, especially between poleis, required an increasing number of armed soldiers. The reserves were sought for among other citizens, who could be motivated to engage in battle by becoming seen as defenders of their homeland. As a result, many lower-class citizens were handed weapons (early $7^{\text {th }}$ century BC). And they were the ones to trigger the change of the character of armed forces, all the more because the change was accompanied by the modernisation of weapons and the substitution of formations of "Homeric" warriors with groups of disciplined hoplites. Many new non-aristocratic

43 B. Bravo, E. Wipszycka, Historia..., pp. 138-142; N.G.L. Hammond, Dzieje..., p. 185 et seq.

44 Ibidem, pp. 141, 194. 
military men appeared to be interested in having a share in power when their armies were victorious. The decline of military aristocracy did not, however, displace the traditional military values. The new army assimilated and developed them further. Hoplites acknowledged they were equal to the aristocratic-Homeric warriors ${ }^{45}$.

Although the Homeric culture of agon, which viewed citizens through their individual performance in battle, lost its significance in the phalanx system, it did not disappear entirely. Individual competition became a trademark of aristocrats struggling to excel in culture and sports. In the hoplite civilisation, in turn, the aristocratic idea of political dispute and ambition became extended, more democratic, and continued to function as such. The aristocratic attitude became more common. On the one hand, some aristocrats and their families vied for absolute power to enjoy a higher rank than other aristocrats. On the other hand, however, aristocracy emphasised the attribute of equality among the members of the class ${ }^{46}$. And like aristocrats, the citizens of various poleis, equal in the eyes of democracy, aimed at assuming power and standing out, which was quite the opposite of what equality was about. The source of conflicts in poleis was therefore an ambition driving people to make a name for themselves.

In the classical period (Aristotle's times), the basic unit of equal value in a polis was a citizen. Polis was clearly interpreted as a "community" (koinonia) of citizens (politai) considered in the context of a system (politaia) expressed by political institutions and the manner in which they were organised in the city. The subjective scope of a polis in the meaning of a city (seat) covered different inhabitants, i.e. men, women, children, and slaves as well. The meaning of a polis understood as a state, in turn, encompassed a community of adult, men only, citizens. Citizenship is treated as the fundamental issue of the Greek culture of polis, and not only in democracy but also in oligarchy and tyranny. Only citizens could hold positions in assemblies, councils, courts or official committees. The idea of citizenship included an individual's membership in a polis, and this membership involved certain political, economic, and social rights and duties ${ }^{47}$.

The civic democracy in a polis, being a "rule of many", of "the people", thus did not mean a rule of all inhabitants. In addition, a Greek civic community (polis) was

45 In his writing he claimed that the economic differentiation between "good" (noble) and "evil" related to the source of wealth. Wealth made on land ownership and farming was generally acceptable. This was not the case with wealth made on various sorts of business. O. Murray, Narodziny Grecji..., p. 291.

46 B. Bravo, E. Wipszycka, Historia..., p. 141.

47 M.H. Hansen, Polis..., pp. 171, 229. 
not very open to foreigners. In economic terms, the societies of such poleis as Athens were based on slavery. Slaves were needed to perform heavy work, and not just because citizens were constantly involved in community affairs. The system "lived off" human exploitation. Keeping this model alive in the Athenian polis was possible thanks to many restrictions, such as the prohibition of marriage between a free Athenian and a slave ${ }^{48}$. Hence the political ethics adopted a division into free people and slaves, into Athenians and foreigners. As mentioned above, another type of division common to poleis was related to one's wealth. Although all citizens had equal rights, the adopted system of democracy was still affected by the position of a family or the wealth of citizens contributing more to a given polis. But such form of "favour" given to some did not mean excluding poorer citizens from making direct decisions on community-related affairs - would be against the idea of polis. The attempts of aristocracy to exercise power in a civic polis faced a strong disapproval, and the means to counteract the threat to political freedom and abuse of power by some, was the institution of ostracism ${ }^{49}$. It involved a temporary expulsion of a citizen from the community, without depriving of citizenship or possessions. The institution was also used as a tool for removing inconvenient political opponents.

\section{Institutions and governance in a polis. Collective institutions of debate and citizen control}

The essence of polis can be seen in political institutions and in their functioning - they shaped and maintained social order and ensured city inhabitants the proper living condition ${ }^{50}$. The institutions of a polis served to establish the binding law, enforce justice, manage taxes, and deal with religion-related, foreign policy, and defence-related issues ${ }^{51}$.

48 Xenophon, Wychowanie Cyrusa /Cyropaedia/, translated by K. Głąbiowski, B. Burliga, A. Marchewka, A. Ryś, Wrocław 2014, p. 106 and footnote 267.

49 The institution was applied for the first time in $487 \mathrm{BC}$.

50 M.H. Hansen, Polis..., pp. 181, 224 and quoted O. Murray (Cities of Reason).

51 Establishing the law, granting citizenship and awarding distinctions to foreigners were of particular importance. As aptly summed up by M.H. Hansen, Polis..., pp. 19, 176-179, in the area of the system of justice, a polis: "passes a sentence, arrests somebody, brings an action on behalf of the citizen, shelters a refuge, appoints a panel of jurors. As for financial matters: it strikes coins, accepts coins struck by other poleis as a legal circulating medium, collects a revenue, defrays expenses, takes up a loan, pays the interest on loans, enters into a contract, owes money, pays fines, buys land, pledges some possessions. As for religious matters: it organises a festival, makes sacrifices to a god, dedicates something to a god, consults an oracle. As for foreign affairs: it sends out envoys and representatives, enters into an alliance, starts wars, goes to war, buries the citizens 
Studies on the institutions of poleis show that most of them tended to have a common set of institutions. It includes: an assembly (ecclesia), a council (boule), sometimes a senate (gerousia), courts (dikasteria), and officials - rulers (archontes). The composition of some institutions was determined by majority election. Power was distributed among the institutions, and the access thereto was limited ${ }^{52}$.

The mechanism of decision-making in a polis deserves a closer attention. Athenian democracy (its public institutions) is shown as an example of a solution making room for a discussion or debate before decisions are made. The marketplace (agora) - the central public space in ancient Greece - was a place where free and equal citizens discussed the matters and affairs of their polis. The discussions would sometimes be transferred to the area of a debate in the people's assembly, which involved public addresses by official rhetores, arguing for and against the considered measures and solutions. Eventually, the outcome of a debate was based on voting, becoming binding upon all citizens. In this deliberation-based model, the position of a citizen in a polis depended on their power of persuasion ${ }^{53}$. This involved, in turn, the ability to convince others. This need was addressed by the Sophists.

Assemblies in some poleis took place not in an agora, but in a different special place (ecclesiasterion). In the classical and Hellenistic periods, assemblies took place in theatres. From the $4^{\text {th }}$ century onwards, i.e. when monumental public buildings started to appear in cities, the agora acted more and more often as a centre of economic and community life. In political terms, a polis meant that the seats of its most important institutions were to be found inside of it. Historical sources speak especially of the prytaneion, where the most important officials of a polis would host and award people and citizens of outstanding merit (e.g. Olympic winners). A significant fact that is mentioned in this context is that the prytaneion featured an altar of Hestia with burning fire, which meant an eternal life of the polis. Other political

killed in war, defects from a league or a ruler, founds a colony". A polis also determined the procedural matters regarding sessions of the people's assembly (ecclesia) and council, appointed officials (selection, draw). Among the regulated issues there were also those from the area of penal, family or inheritance law, with the matters of manufacturing or trading given less attention. The regulations regarding economy especially concerned "taxes and duties, taking loans from temples and paying them off, and ensuring regular supplies of corn for the city". The regulations regarding foreign policy covered: "declaring a war, peace treaties and alliances, mobilisation of land forces and navy, maintaining fortifications in the right condition". There were some comprehensive regulations concerning organising and financing religious holidays that had to be celebrated throughout the year. Many decisions were also made in the form of granting citizenship and honorification decrees, not just to citizens of poleis.

52 M. Cross, The Creativity of Crete. City States and the Foundations of the Modern World, Signal Books Oxford, 2011, p. 106.

53 P.W. Juchacz, “Demokracja ateńska a współczesne koncepcje demokracji deliberatywnej. Glosa do teorii demokracji", in: Filozofia a demokracja, ed. by P.W. Juchacz, R. Kozłowski, Poznań 2001, p. 270. 
'attributes' of a polis included a council building (bouleuterion) and a court seat (dikasteria), which was sometimes located in a separate building ${ }^{54}$.

It has been already mentioned that a polis was a "community" (koinonia) of citizens, considered in the context of a system (politaia) expressed by political institutions and the manner in which they were organised in the city. These related terms, i.e. polis, polites, and politeia prove that the core of the idea of polis is a civic community, i.e. people who take part in the activity of political institutions of their polis. Speaking more precisely, politeia is described as "a structure of political bodies (archai) of a polis, especially the body that governs all" (Aristotle). According to Aristotle's accounts, in $4^{\text {th }}$-century Greece there were democracies and tyrannies, but in poleis with different systems (in the majority thereof) the same institutions existed, although not with the same range and type of competence. A specific example is the system adopted in Cyrene ("moderate oligarchy") from around year $322 \mathrm{BC}$. It was defined in a constitution inscribed on a stele (it is the oldest known text of a constitution in the world $)^{55}$.

The view of a polis as a state being and a society where an individual is subject to meticulous controlling mechanisms in both the public and private spheres ${ }^{56}$, common in the past, is treated now rather as a reference to the description of the ideal state as understood by Plato and Aristotle (Politics, Books VII and VIII). A quite common image of a polis as a community supervising citizens' behaviour in all spheres of life (religion, family and marital relations, manufacturing and trading, upbringing and education, residential affairs) was rather typical of the Spartan polis. It is usually claimed that this model of life in a polis was not in line with the general democratic vision of a polis. Closer to this model was the Athenian approach, differentiating between the area of public and private activity. While the former focused on matters concerning the polis and politics only, the latter was of lesser importance to the law in place. This concerned not only economic activity but also upbringing, education or family relationships. While the Spartan polis involved a significant connection between the state and the society, the Athenian model tended to separate the public from the private. In the latter, the freedom of an Athenian stretched as far as to the limits of a rather "liberation-oriented" law. In the private sphere of life, an Athenian could live their life doing as they please provided that they do

\footnotetext{
$54 \quad$ M.H. Hansen, Polis..., pp. 159-160.

55 Ibidem, Polis..., pp. 172-173, 177 and quoted: Aristotle, Politics, 1278 b8-10. The constitution of Cyrene organised civic and political rights and regulated the functioning of political institutions, i.e. the people's assembly, the boule, the council of elders, official collegia, including the collegium of five strategoi, elected by the assembly and governing together with a permanent strategos.

56 A. Ryan, On Politics. A History of Political Thought..., p. 6.
} 
not violate the law. The principle was preferred among democrats as a sort of ideal while the critics of the people's rule considered it a flaw of democracy ${ }^{57}$.

\section{Conclusions}

The Greek polis was a community of citizens in an urban living setting. But the feature of such a city was not only its separation from the surrounding farmlands - it functioned as a centre of some territory, and local farmers were citizens of such a polis. Every polis was governed by its own rules, promising both independence from other poleis and civic freedom ${ }^{58}$.

Polis served many purposes. It was a centre of matters concerning and involving politics, religion, defence, economy, education, culture, sports, and entertainment. As a city, a polis occupied a given territory, usually surrounded by walls, and was inhabited by different people, not only its citizens. A polis treated as a state (political community), in turn, denoted: 1) the territory of a state (the city with its surroundings), 2) the citizens of a state, and 3) the institutions of a state ${ }^{59}$. A polis was therefore a specific state organism functioning in the form of a community of citizens. Such an organism was built of equal, free, land-owning citizens, enjoying certain political rights and obliged to fulfil certain political duties. Poleis had several different dimensions, with the political-social and religious ones considered to be greatest importance. The essential components of a polis were the agora and a temple. Those small communities, living scattered across small areas, were the bedrock of classical, direct democracy. And it was the collective institutions of poleis, especially of the democratic ones, that offered the ground for a spectacular development of discursive reasoning, perfecting its quality.

Based on a comparison of the system adopted in the Greek culture of polis with the systems adopted in many other city-state cultures, it is argued that most of those cultures featured states ruled by monarchs, and sometimes as oligarchies or democracies. In the case of a republic, its origins are found mainly in the oligarchic or aristocratic systems adopted in city-states. Democracy as a common political system is found only in the case of the Greek culture of polis, with a special case of Athens ${ }^{60}$.

\footnotetext{
57 M.H. Hansen, Polis..., pp. 191-193, 285 and quoted Thucydides, as well as Finley, Ostwald, Popper and Hornblower.

58 Xenophon, Wychowanie Cyrusa /Cyropaedia/..., p. 65, footnote 7.

59 M.H. Hansen, Polis..., pp. 159, 164 et seq.

60 M.H. Hansen, Polis..., p. 228-229; N.G.L. Hammond, Dzieje..., pp. 198-245, 351 et seq.
} 
The conditions of the emergence of a civic polis (political community) in Greece are still not sufficiently clear. The longevity of the polis culture, in turn, is explained in a much more convincing way - the reason behind it is supposed to be in the area of mentality ("polis has left a lasting and very deep imprint on people's behaviour, on their way of thinking, making them unable to accept other forms of political life"). The thesis is based e.g. on the duration of the polis system in the monarchies of the Hellenistic period and in the age of the Roman Empire. They are also to express the main qualities of a style of thinking developed in the times of poleis, and the disappearance thereof is to be related to the fall of the ancient world ${ }^{61}$.

The above considerations show that the essence of polis since the archaic age had been to exercise power in a specific manner. A model interpretation of the term points to a community of citizens, characterised by independent and autonomous governance exercised by those citizens. In this community, citizens do not form public structures isolated from the society and the aim to represent the interests of the community. Power is said to have been "passed around" citizens, who changed places as decision-makers and those subject to the decisions being made. The most important decisions are made by collective bodies after a public debate. Over time, this debate became the main political instrument, the interest in which translated into a need to develop the mental abilities of citizens and to produce literature and styles contributing thereto. Those abilities made it possible to engage in political and court disputes ${ }^{62}$. Understanding the features of a civic polis is a prerequisite to the understanding of Greek culture.

The demise of Greek poleis does not mean that the vision of city-states has become obsolete. Contemporary studies into the culture of city-states (small structure) and large states referred to as "country-states" prove that with the development of the Enlightenment vision and practice of large states, the political models characteristic of poleis gained a new life and started spreading across "country-states". It has been shown that until the $18^{\text {th }}$ century, "country-states" were monarchies, while city-states were not only monarchies but also oligarchies and democracies. In the case of the latter two, political decisions were made by people's assemblies (democracy) and elected councils (oligarchy), with each such decision generally made after a public discussion by way of a majority vote. All of these systems make use also of certain mechanisms of selecting and changing leaders. What was once practised in city-states (micro-states) paved the way for the debate in the $18^{\text {th }}$-century revolutionary France and in the emerging United States of America. The inspiration of the ancient vision of a democratic and oligarchic polis is ascribed

61 B. Bravo, E. Wipszycka, Historia..., p. 137.

62 See e.g. B. Bravo, E. Wipszycka, Historia..., pp. 134-135. 
especially to Rousseau. The founders of the United States of America took the political model in the form of a federation of small poleis to the level of a macro-state. At present, federal country-states with their roots in the city-state culture are home to around half of the world's population. The consequence of the federal model is a sort of hierarchic vision of the state. This entails a pattern in the form of a hierarchic arrangement of city-states, whose important quality was "internal" sovereignty (autonomy) - but not "external" sovereignty (independence). Finally, the development of cities was accompanied by the development of the economy. While a self-sufficient economy is typical of low-urbanised settlements, a market economy is characteristic of high-urbanised societies. The evaluation of city-states from the socio-economic point of view shows that their culture leaned towards urbanisation and a free market. Some (like John Hicks) even claim that city-states gave birth to an early model of a contemporary market economy ${ }^{63}$. More moderate opinions regarding the evaluation of the economy and trade in poleis point not as much to a model as to the roots of market economy to be found in the culture in question. The biggest trade poleis, such as Athens or Crete, contributed, in particular, to the emergence of the concept of the said type of economy.

Studies on the autonomy (autonomia) of poleis, a feature that was not permanent, prove substantial to the contemporary reflection on the sovereignty or autonomy of states. Apart from autonomous poleis there were also a number of poleis dependent on a dominant polis or functioning as part of an association or a federation. Such a diverse approach to autonomy can also be encountered today, with one example being the European Union, the membership in which changes the traditional perception of state autonomy. This point of view reveals certain similarities between the organisational solutions concerning states and poleis ${ }^{64}$. Hence the consideration of the new vision of the state in the global world of today may benefit from the reflection on city-states. Especially since this world is becoming increasingly urbanised.

Lastly - and importantly, poleis as highly diversified organisms (not just in terms of political systems) provided good conditions for culture to develop and for their citizens to learn. In some cases, this led to the emergence of specific thinking that expected one to argue for the professed beliefs in a "hard", concrete (non-mythical) manner. It made it possible for scientific and philosophical thought to develop - the Greek mythological vision assumed the development of the universe from a chaotic being to a fully organised and harmonious world. This polis had gone through various systems, ending with democracy as a system and as the adopted legal order. It is this world, represented by Miletus, Ephesus, and Athens,

\footnotetext{
63 M.H. Hansen, Polis..., pp. 22-26.

64 Ibidem, pp. 98-99.
} 
where mature, critical thinking of the regularities governing cosmos, poleis, and humans appeared and where the thought of the significance of the rule of law and the meaning of philosophy emerged. The idea of an aristocratic lifestyle as described by Homer and - to some extent - by Hesiod played a major part in the development of communities in poleis. This idea contains a vision of certain values, a concept of bravery and progress-inducing competition, and the roots of warning against turning towards hubris ${ }^{65}$. Although the descriptions of ancient poleis, their rules and ideas do not provide any direct information of the dramatic nature of the life lived in the "free competition" environment of the time, the general notions such as: citizenship, democracy, equality, autonomy, self-governance or justice express an aspiration for a better life of an individual in a community. The democracy of classical times, characterised by citizens being equal taking precedence over law and freedom of speech, is considered as the one to moderate fierce social-economic disputes for the first time in the history of mankind. Its innovative nature has become reflected in the language as a feature strongly connected with society ${ }^{66}$. Thus, the language of the contemporary post-liberal vision of total rivalry aimed at making money to serve financial markets does not express the thought of peace and stability among people. And this is where it is hard to expect Aristotle to argue for the naturalness of the neo-market aspiration to riches ${ }^{67}$.

\section{References}

Arystoteles, Polityka, transl. L. Piotrowicz, Warszawa 2004.

Bravo B., Wipszycka E., Historia starożytnych Greków, t. I, Do końca wojen perskich, Warszawa 1988.

Cross M., The creativity of Crete. City States and the Foundations of the Modern World, Signal

Books Oxford, 2011.

Długosz J., Obywatel hoplita, appendix to „Polityka” 23.03.2006.

65 On hybris, see e.g. J. Oniszczuk, Przedfilozoficzna norma i hybris, „Państwo Prawne”, Vol. 1(7) 2017, p. 7 et seq.

66 A. Missiou, The Vocabulary of Democracy, in: A History of Ancient Greek. From the Beginnings to Late Antiquity, translated by D. Whitehouse, ed. by A.F. Christidis, Cambridge University Press 2007, p. 1062.

67 "There are al two sorts of wealth-getting, as I have said; one is a part of household management, the other is retail trade: the former necessary and honourable, while that which consists in exchange is justly censured; for it is unnatural, and a mode by which men gain from one another. The most hated sort, and with the greatest reason, is usury, which makes a gain out of money itself, and not from the natural object of it. For money was intended to be used in exchange, but not to increase at interest. And this term interest, which means the birth of money from money, is applied to the breeding of money because the offspring resembles the parent. Wherefore of any modes of getting wealth this is the most unnatural". Aristotle, Politics (Book 1, Chapter 10). 
Hall J.M., Polis, Community, and Ethnic Identity, in: The Cambridge Companion to Archaic Greece, ed. H.A. Shapiro, Cambridge University Press 2007.

Hammond N.G.L., Dzieje Grecji, Warszawa 1994.

Hansen M.H., Polis. Wprowadzenie do dziejów greckiego miasta-państwa w starożytności, Warszawa 2011.

Herodot, Dzieje, tł. S. Hammer, Warszawa 2004.

Juchacz P.W., Demokracja ateńska a wspótczesne koncepcje demokracji deliberatywnej. Glosa do teorii demokracji, in: Filozofia a demokracja, eds. P.W. Juchacz, R. Kozłowski, Poznań 2001.

Krawczuk A., Mity, mędrcy, polityka, Warszawa 1975.

Ksenofont, Wychowanie Cyrusa /Cyropaedia/, trans. K. Gląbiowski, B. Burliga, A. Marchewka, A. Ryś, Wrocław 2014.

Kulesza R., Sparta w V-IV wieku p.n.e., Warszawa 2003.

Lengauer W., Starożytna Grecja okresu archaicznego i klasycznego, Warszawa 1999.

Mieroop van de M., The Ancient Mesopotamian City, Oxford 1997.

Missiou A., The vocabulary of democracy, in: A History of Ancient Greek. From the Beginnings to Late Antiquity, ed. A.-F. Christidis, Cambridge 2007.

Murray O., Narodziny Grecji, trans. A. Twardecki, Warszawa 2004.

Odyseja, trans. L. Siemieński, Warszawa 1990.

Oniszczuk J., Hezjod: prefilozofia pracy, sprawiedliwości i hybris, in: Prawo pracy. Między gospodarka a ochrona pracy. Księga jubileuszowa Profesora Ludwika Florka, Warszawa 2016.

Oniszczuk J., Homer: zasada miary, hybris i absurd "sprawiedliwości", in: Wspótczesny matrix? Fikcja w życiu gospodarczym politycznym i spolecznym, ed. J. Osiński, Warszawa 2015. Oniszczuk, Przedfilozoficzna norma i hybris, „Państwo Prawne” 2017, No. 1(7).

Patzek B., Homer i jego czasy, Warszawa 2007.

Reale G., Historia filozofii starożytnej, Vol. 1, trans. Edward I. Zieliński, Lublin 2008.

Ryan A., On Politics. A History of Political Thought. From Herodotus to the Present, Book One, Liveright Publishing Corporation, New York/London 2012.

Szczęśniak M., Nauka a demokracja, in: Filozofia a demokracja, eds. P.W. Juchacz, R. Kozłowski, Poznań 2001.

Zieliński T., Grecja niepodległa, Warszawa 1995. 